\title{
汀線と海浜断面積変化量を指標とした 海岸堤防の被災限界
}

\author{
袴田 充哉 1 宇多 高明 2 ・貝沼 征嗣 3 \\ 1 静岡県交通基盤部河川砂防局河川海岸整備課（干420-8601 静岡県静岡市葵区追手町 9 番 6 号） \\ E-mail: kasen@pref.shizuoka.lg.jp \\ 2 正会員 （一財）土木研究センターなぎさ総合研究所兼日本大学理工学部海洋建築工学科 \\ （干110-0016 東京都台東区台東 1-6-4） \\ E-mail: uda@pwrc.or.jp \\ 3 静岡県交通基盤部河川砂防局河川企画課（干420-8601 静岡県静岡市葵区追手町 9 番 6 号) \\ E-mail:kasenki@pref.shizuoka.lg.jp
}

\begin{abstract}
海岸堤防（護岸）が汀線後退とともにその安定性が失われる危険性を現場で簡便に判断する一つの指標 として，堤防前面の浜幅と定期縦断測量データから算出される海浜断面積を組み合わせた方法について検 討した。遠州灘に面した竜洋海岸，浜松五島海岸および浜松篠原海岸での海岸堤防（土堤）の被㷋事例を もとに, 空中写真から算出した浜幅の履歴と海浜断面積の経年変化より，堤防の被災限界の目安を示した.
\end{abstract}

Key Words : seawall, damage potential, shoreline change, cross-shore area of the beach, beach width

\section{1. まえがき}

海岸堤防（護岸）は，堤防前面の前浜が狭まってのり 先が直接波に曝された状態になると背後の裏込め土砂が 吸出され，表のり面の陷没などが起きて堤防の安全性が 損なわれることが多い，その機構は，構造物周辺での砂 移動に関係するので複雑であるが，ある海岸に設置され ている堤防が汀線の後退とともにその安定性が失われる 危険性を現場で簡便に判断する一つの指標として, 海岸 巡視などで容易に観察できる堤防前面の浜幅が考えられ る. 堤防前面の浜幅が十分広ければ堤防の安全度は相対 的に高いが, 前浜が狭まれば危険度が増寸と考えられる. しかし同じ浜幅を有していたしても，海浜勾配が緩く堤 防前面の水深が小さい場合と, 堤防前面の水深が大きい 場合では堤防の安定性は大きく異なり，堤防前面の水深 が大きいほど堤防の安全度が低下寸ると考えられる.こ れを考慮すると, 安定性評価の精度をできるだけ高める には，堤防前面の水深の大小をも評価することが必要と なる. この点に関しては，多くの海岸で定期的に行われ ている縦断測量のデータを用いれば，堤防前面の海浜勾 配，または海浜断面積を用いて堤防前面の水深の違いを 評価可能と考えられる ${ }^{1)}$. 本研究では, 遠州灘に面した 竜洋・浜松五島・浜松篠原海岸での海岸堤防（土堤）の 被災事例をもとに, 浜幅と海浜断面積の両面から堤防の
被災限界の目安を得る方法について検討した.

\section{2. 海岸堤防の被災限界の考え方}

堤防前面の前浜と堤防の安定性について，図-1の模式 図をもとに考える. 堤防は一般に基礎工を有しているが, 前浜が狭まって堤防ののり先水深が増せば安定性が低下 する. したがって堤防の安定性はその前面の砂浜の規模 に強くかかわる.ここで対象とする海浜は, 一般にはバー 厶高 $\left(h_{\mathrm{R}}\right)$ から波による地形変化の限界水深 $h_{\mathrm{c}}$ (遠州灘 海岸にあってはほぼ $10 \mathrm{~m}$ 程度）までに堆積している砂 の塊である. 海浜縦断形は波浪条件に依存して様々変化 するが，いま図-1 の模式図に示す縦断形を有していたと 寸る. この場合, 堤防基部に定めた基淮線からの沖向き 距離として定めた浜幅 $B$ と海浜断面積 $A$ が, 堤防の被災

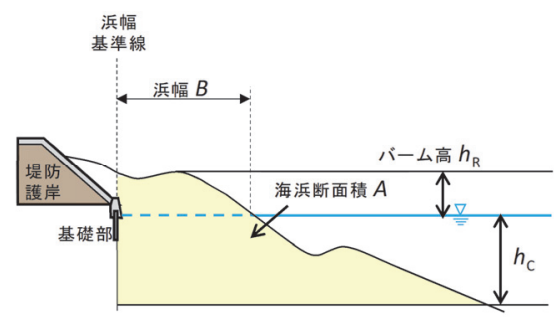

図-1 堤防前面の浜幅と海浜断面積の定義 


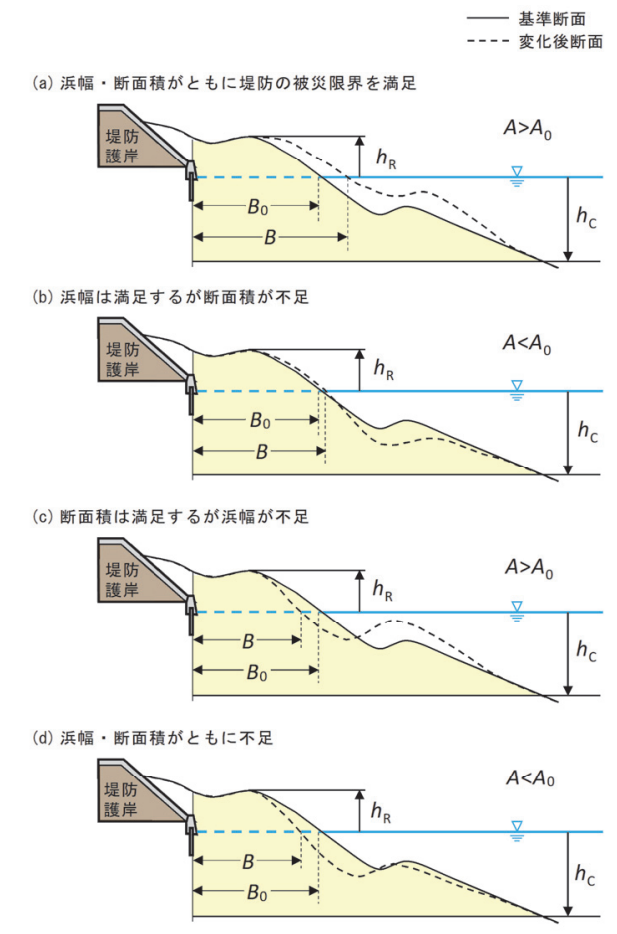

図-2＼cjkstart浜幅と海浜断面積による海浜状況の分類

限界を定める限界浜幅 $B_{0}$ ，および限界断面積 $A_{0}$ を満足 するかどうかにより堤防の安定性評価は 4 種に分類され る（図-2）。まず，浜幅 $B$ および海浜断面積 $A$ がともに 浜幅・海浜断面積の限界值を満足する条件では，堤防の のり先が砂浜で守られているため堤防は安定である（図 -2(a)). 図-2(b)は，汀線沖が掘られて急深となった場合 で，浜幅は $B_{0}$ を満足するものの汀線沖が深くなって $A$ が $A_{0}$ を満足できない場合である.これと逆に, 汀線付近 が掘られて砂が沖向きに運ばれた場合の地形変化を図 -2(c)に示す. $A$ は $A_{0}$ を満足するが， $B$ が $B_{0}$ より狭まり， 汀線が堤防ののり尻に接近し，堤防ののり先が露出し堤 防の被災度が増す．図-2(d)は沿岸漂砂の流出に伴い縦断 形が陸向きに平行に後退した場合であって，浜幅 $B$ と海 浜断面積 $A$ が被災限界を満足せず，浜幅が狭まって急深 となった場合である. 以上に示寸地形変化は，波浪条件 に依存するが，波作用後の縦断形に着目すれば，実際の 堤防の被倓の限界条件が与えられていることから，それ らの条件が満足されるかどうかにより堤防の安定性の評 価が可能と考えられる.

\section{3. 事例検討}

\section{(1) 竜洋海岸}

図-3 は検討対象の一つの竜洋海岸の 2017 年 11 月撮影 の空中写真を示す。この海岸は天竜川河口の東側に位置 し，東向きの沿岸漂砂が卓越している. 図には測線番号 も示す．当海岸では，1992 年 9 月 13 日に太平洋沿岸を 通過した台風 18 号による高波浪が堤防に直接打ち寄せ た結果，堤防のり面背後の土砂が吸い出され，堤防天端 が陷没した災害 2)を契機として 1993〜1997 年に堤長 100 〜 158 m の 1〜5 号離岸堤が造られた. これにより被災箇 所では堤防前面の前浜が回復したが，離岸堤群の東側で は汀線が後退し，堤防ののり先が波に曝された。このた め, 現在ではその下手側に 6 号離岸堤が設置されている. この間，図-3 の測線 No.196 では2007 年 7 月に著しい侵 食が起こり，堤防（土堤）が破壊された。

堤防の被災は沿岸方向にかなり広い範囲での地形変 化と密接に関係している，そこで，図-4には堤防が被災 した No.196 を含む区域の 1993～2008 年の汀線変化を示 す. 同時に, 1993 年の空中写真から読み取った汀線形状 を図に記入した. 1993 年には対象区域の西端では浜幅が $20 \mathrm{~m}$ と狭かったが，浜幅は東向きに増大し，後に堤防が 被災する測線 No.196 では幅 $120 \mathrm{~m}$ の前浜があった. その 後，1997 年までに 1〜5 号離岸堤が造られると，東向き の沿岸漂砂がこれらにより阻止され，東端の 5 号離岸堤 の東側直近で汀線の後退が始まった. その後 2008 年まで に，No.195〜No.201 の $1200 \mathrm{~m}$ 間で堤防が波に直接曝さ れる状態となり，浜幅が極端に減少したため，2007 年 7 月にはNo.196 付近で堤防が破壊された.

図-5 には No.196 における浜幅と海浜断面積の経年変 化を示す。ここに海浜断面積の計算では宇多ら 3)を参照 し, $h_{\mathrm{R}}=3 \mathrm{~m}, h_{\mathrm{c}}=9 \mathrm{~m}$ とした. 浜幅は 1993 年以降変動を 伴いながら減少し，堤防が被災した 2007 年 7 月直前の 2007 年 2 月には $23.5 \mathrm{~m}$ まで狭まった。海浜断面積の変 化も浜幅の変化とよく似た変化を遂げ，同じく堤防が破 壊される直前には $1982 \mathrm{~m}^{2}$ の最小值を示し，砂浜の根固 め効果が大きく損なわれた. よって竜洋海岸の場合には, 浜幅 $23.5 \mathrm{~m}$ と最小海浜断面積 $1982 \mathrm{~m}^{2}$ が堤防の被災限界

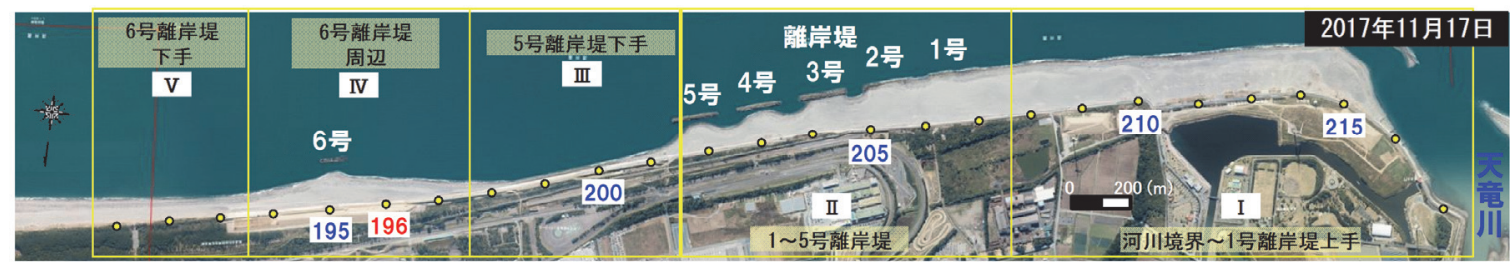

図-3＼cjkstart竜洋海岸の空中写真 (2017 年 11 月) 


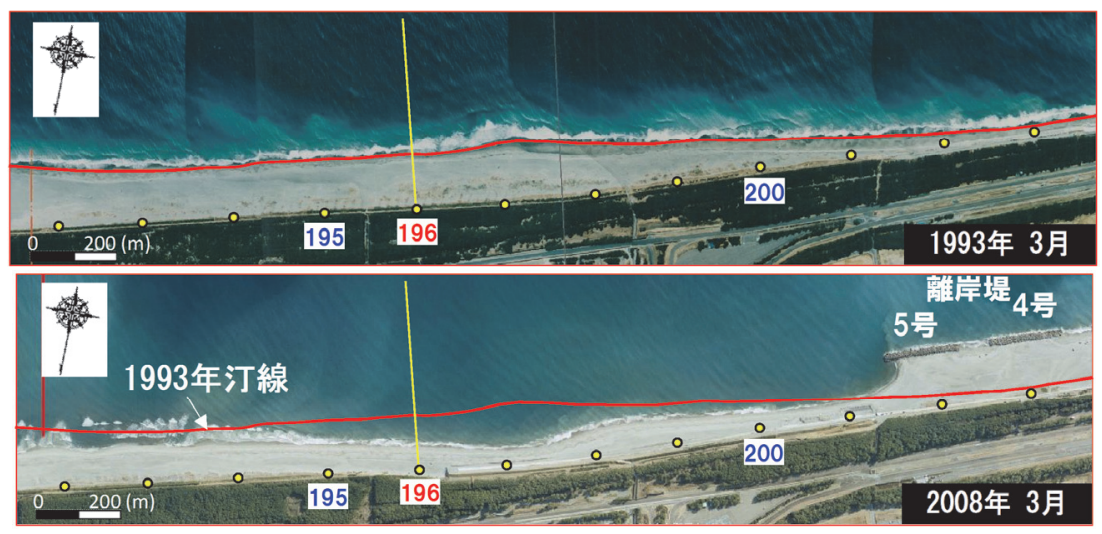

図-4＼cjkstart竜洋海岸の変化（1993 年 vs 2008 年）

の目安を与えると考えられる．そこで浜幅と海浜断面積 から見た被災限界を基準值と考え，沿岸方向の各測線に おいて算出した浜幅と海浜断面積が上記基準值を満足す るかどうかについて調べた. まず，No.191〜No.214の沿 岸方向 $4.4 \mathrm{~km}$ 区間の全測線で浜幅と海浜断面積を求め, 上記基準值とともに図-6に示した．浜幅と海浜断面積に ついては 2018, 2019 年のデータを示す。図-6 によれば, 2018, 2019年の浜幅と海浜断面積とも 1 5 号離岸堤の西 側では基準值より十分大きな值であるが，5 号離岸堤の 東側の No.198〜No.201 では浜幅が基準值を下回った. 同 様に海浜断面積は No.198〜No.201 だけでなく，No.191 〜No.193 でも基準值を満足できていない. さらに図-6に 示す浜幅と海浜断面積の沿岸分布によれば，区域ごとに

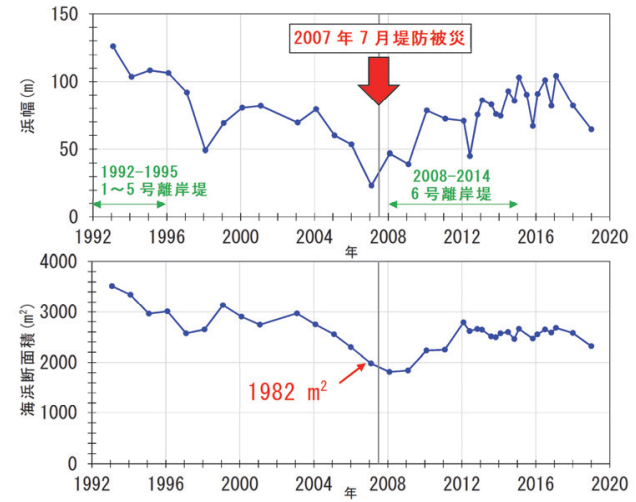

図-5＼cjkstart測線 No.196における浜幅と海浜断面積の経年変化

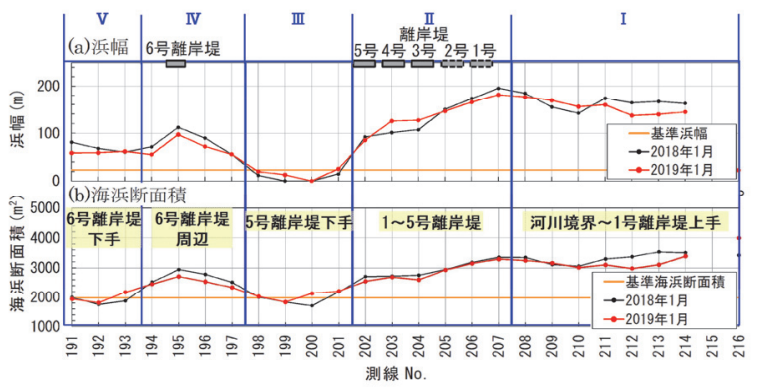

図-6＼cjkstart竜洋海岸における浜幅と海浜断面積の沿岸分布
特徵が見られることから，離岸堤などの施設との関係を 考慮して天竜川河口から東向きに区域 I V (区域 I : 天 竜川河口 1 号堤, 区域 II : 1 5 号堤, 区域 III : 5 号堤 東側, 区域 IV $: 6$ 号堤周辺, 区域 $\mathrm{V}: 6$ 号堤の東側）を 定め, これら区域ごとに浜幅と海浜断面積の関係を調べ た（図-7）。なお，区域 I では浜幅と海浜断面積とも基準 值を十分上回っていることから図は省略した。

まず, 区域IIでは区域I と同様に堤防は安定であった。 これに対し，区域 III では浜幅は基準值を下回り，海浜断 面積も小さくなり, とくにNo.199 では基準值を満足して いない，一方，区域 IV では区域 I, II と同様，再び基準值 を満足している．区域 V では，浜幅は基準值を満足して いるが, No.191, 192 では浜幅は基準值を満足しているに もかかわらず，海浜断面積が基準值以下となっていた。

\section{(2) 浜松五島海岸}

天竜川の河口右岸に位置する浜松五島海岸でも同様 な検討を行った．浜松五島海岸の 2017 年 11 月撮影の空

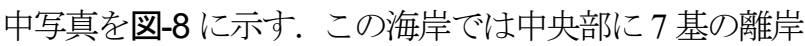
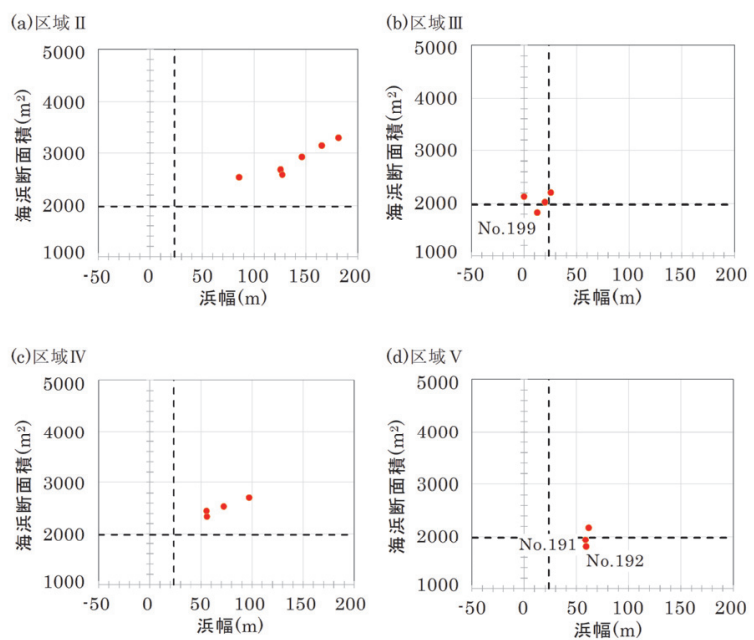

図-7＼cjkstart浜幅と海浜断面積の関係（竜洋海岸） 


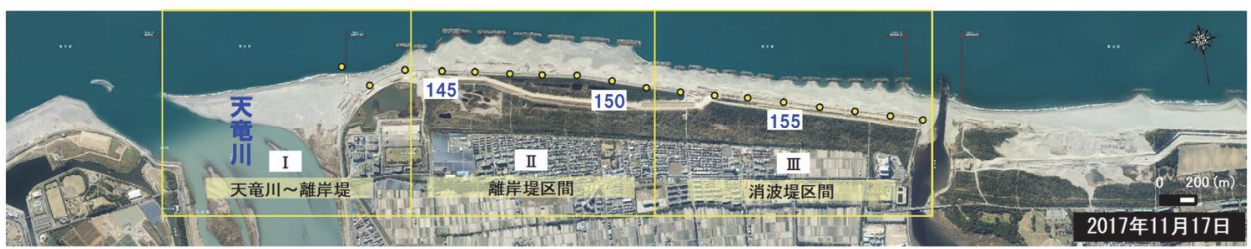

図-8＼cjkstart浜松五島海岸の空中写真 (2017 年 11 月)

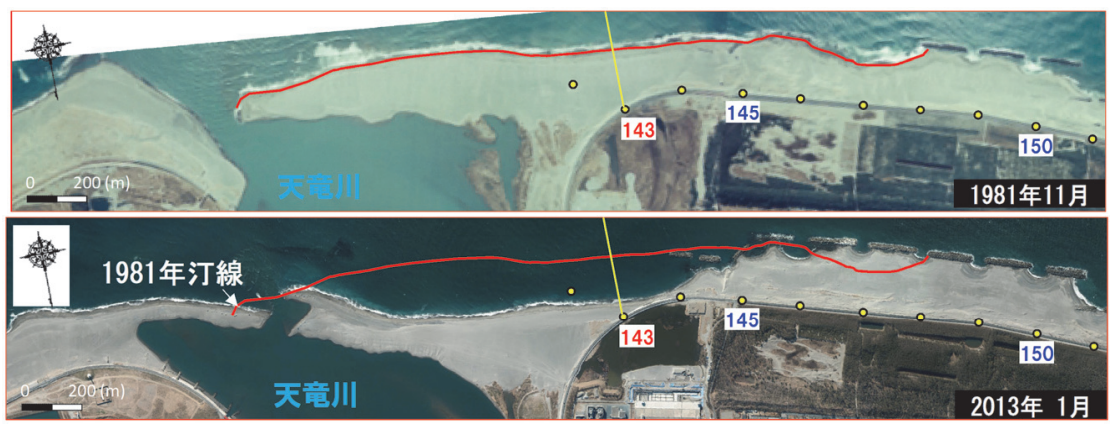

図-9＼cjkstart浜松五島海岸の変化（1981 年 vs 2013 年）

堤が，またその西側，馬込川河口までの $1.6 \mathrm{~km}$ 区間には 13 基の消波堤が設置されている. 過去には天竜川の流出 土砂は河口から西向きに流れていたが，現況では離岸堤 群が沖向きに大きく突出しているためこの沿岸漂砂の大 半は阻止されており, 離岸堤群沖では侵食が進んできて いる. 一方, 離岸堤群の東端では天竜川河口砂州の変動 とともに東向きの漂砂も起こり, 結果的に汀線変動が大 きい. そこで図-9には空中写真から読みとった河口左岸 付近の汀線変化を示す. 1981 年には幅広い河口砂州が右 岸側から伸びていたが, 2013 年までに離岸堤群の東側で の汀線後退が顕著となり, 河口砂州の中央付近での汀線 後退量は $200 \mathrm{~m}$ となった. 堤防の越波被害が出たのは困 に示す河口右岸の測線 No.143 付近である. 2013 年 10 月 の台風 26 号の襲来時には測線 No.143 付近で堤防への越 波が起き, 天端高 T.P.+6.12 m の堤防への越波により裏の りに設置されていた自転車道のフェンスが倒壊する被害 が出た. 被害が発生した測線 No.143 での浜幅と海浜断面 積の経年変化を図-10 に示す. ここに海浜断面積の計算 では長島ら 4)を参照し， $h_{\mathrm{R}}=3 \mathrm{~m}, h_{\mathrm{c}}=12 \mathrm{~m}$ とした. 1996 年から 2010 年までは測量データがないので直線近似と したが, 1994 年以前には浜幅は $250 \mathrm{~m}$ と十分広く, 海浜 断面積も $6300 \mathrm{~m}^{2}$ 以上あったが，1996 年以降これらは減 少し，2010 年には浜幅は $73.2 \mathrm{~m}$, 海浜断面積は $4815 \mathrm{~m}^{2}$ まで減少した。そして自転車道の被災時には浜幅は 53.7 $\mathrm{m}$, 海浜断面積は $4479 \mathrm{~m}^{2}$ まで減少した. よってこの海 岸では，被災限界を与える意味での浜幅と海浜断面積の 基準值の目安は，それぞれ $53.7 \mathrm{~m}$ と $4479 \mathrm{~m}^{2}$ で与えられ ると考えられる. 図-11 は浜松五島海岸全体を対象とし て，2017，2018 年のデータをもとに算出した浜幅と海浜 断面積の沿岸方向分布を示す. 図には浜幅と海浜断面積
の基準值も示す. 図に示すように，離岸堤群の東側を区 域 I，離岸堤区間を II,消波堤区間を III とすると，区間 II, III ではこれらの基準值を十分満足している. 図-12 には 被災判定のための基準值と上記 3 区域での浜幅と海浜断 面積の関係を示す. No.144 では浜幅は満足しているもの の，海浜断面積は基準值を満足しておらず，防災上注意 すべき場所であることが分かる。これに対し，区域 II, III ではいずれの測線でも基準值を満足している.
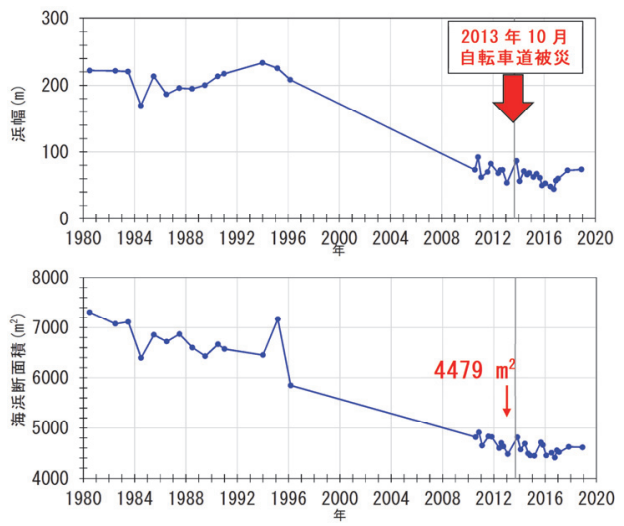

図-10 測線 No.143 における浜幅と海浜断面積の経年変化

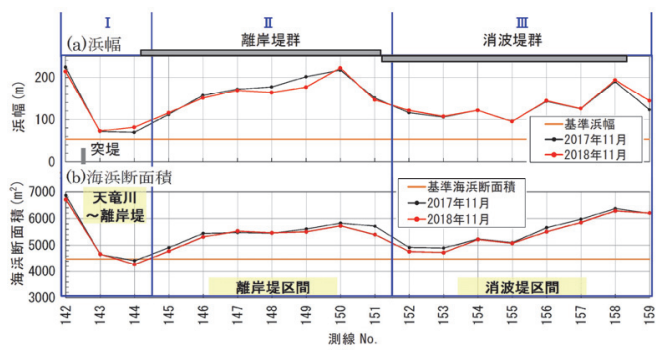

図-11 浜幅と海浜断面積の沿岸分布（浜松五島海岸） 

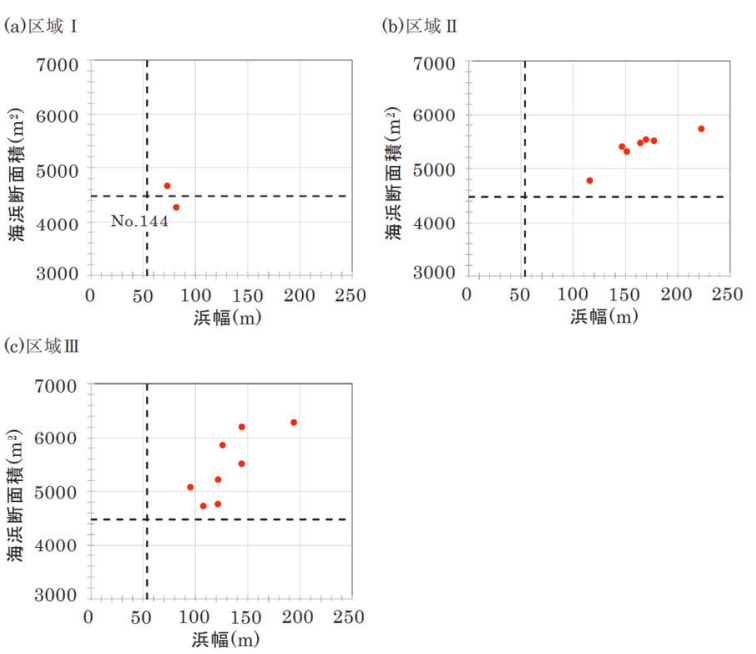

図-12＼cjkstart浜幅と海浜断面積の関係（浜松五島海岸）

\section{(3) 浜松篠原海岸}

浜松五島海岸の西側に位置する浜松篠原海岸につい ても同様な検討を行った。 まず図-13 には浜松篠原海岸 の 2017 年 11 月の空中写真を測線番号とともに示す. 当 海岸は馬込川河口の西側にあり, 2003 年 4〜10 月には中 田島砂丘の東部で侵食が進んだ。当海岸では西向きの沿 岸漂砂が卓越していることから，図-13 に示すように東 側から西側へと 4 区域（区域 I: 馬込川〜中田島砂丘，II: 中田島砂丘, III: 離岸堤区域, IV: 離岸堤の西側区域）を 設定した. まず, 空中写真をもとに対象区域の 1981 年と 2004 年の汀線形状を調べた結果を図-14 に示す. 1981 年 には中田島砂丘の前面には幅 $155 \mathrm{~m}$ の広い前浜があり,
馬込川河口から西向きに直線状の汀線が伸びていた。そ の後, 馬込川河口の西側隣接部から汀線の後退が始まり, 2004 年までに中田島砂丘前面の区域 II では最大で 145 m と大きく後退した.

中田島砂丘東部で 2003 年に著しい侵食が起きた場所 は測線 No.160 である. そこでこの測線における浜幅と海 浜断面積を求め，その経年変化を調べた（図-15）。海浜 断面積は, 海浜縦断形の比較から定めた $h_{\mathrm{c}}=12 \mathrm{~m}$ を用い て計算した. 図によれば, 浜幅は1981 年より徐々に減少 し，1989～2001 年には75 m 程度の值を保っていたが, 2002 年から急減し, 2003 年の著しい侵食時には浜幅は $27.9 \mathrm{~m}$ となり, その後 2004 年には $5.3 \mathrm{~m}$ まで大きく減少 した. しかし 2006〜2012 年には粗粒材養浜が行われ，離 岸堤も建設されたことにより浜幅は増加傾向に変わり, 2012 年には浜幅は $135 \mathrm{~m}$ まで回復した. 図-16 には海浜 断面積の変化も示す，海浜断面積は災害が起きた 2003 年までは浜幅と似た変動を示し，災害時には海浜断面積 の最小值 $5991 \mathrm{~m}^{2}$ を示した. 浜幅は粗粒材養浜と離岸堤 建設により 2006 年以降増加に転じたのに対し, 海浜断面 積の増加は一時的であり，全体的には減少傾向が続いて いる.これは汀線付近では堆砂量が増加したのに対し， 沖合を含めると海浜断面積は低減傾向にあることを意味 している．図-15 によれば，浜松篠原海岸にあっては堤 防 (土堤) の被災限界は浜幅が $27.9 \mathrm{~m}$, 海浜断面積が 5991 $\mathrm{m}^{2}$ でほぼ与えられると考えられる. そこで以下ではこれ らを基準值と考え，沿岸方向の各測線での変化について 調べた．図-16 には 2017 年と 2019 年のデータをもとに 求めた各測線での浜幅と海浜断面積の沿岸方向の変化を

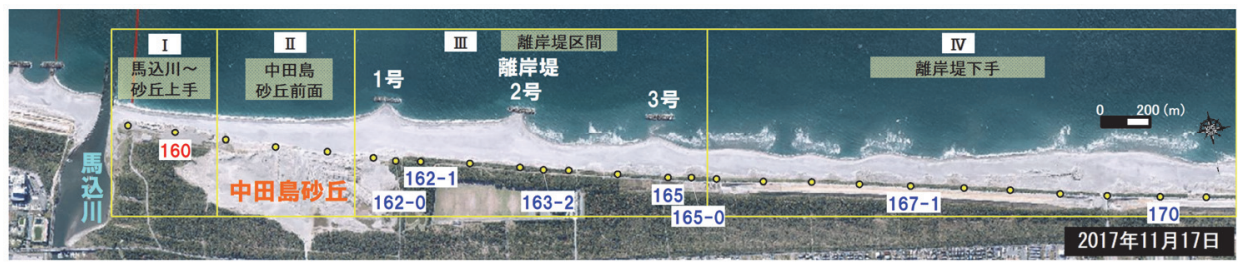

図-13＼cjkstart浜松篠原海岸の空中写真 (2017 年 11 月)
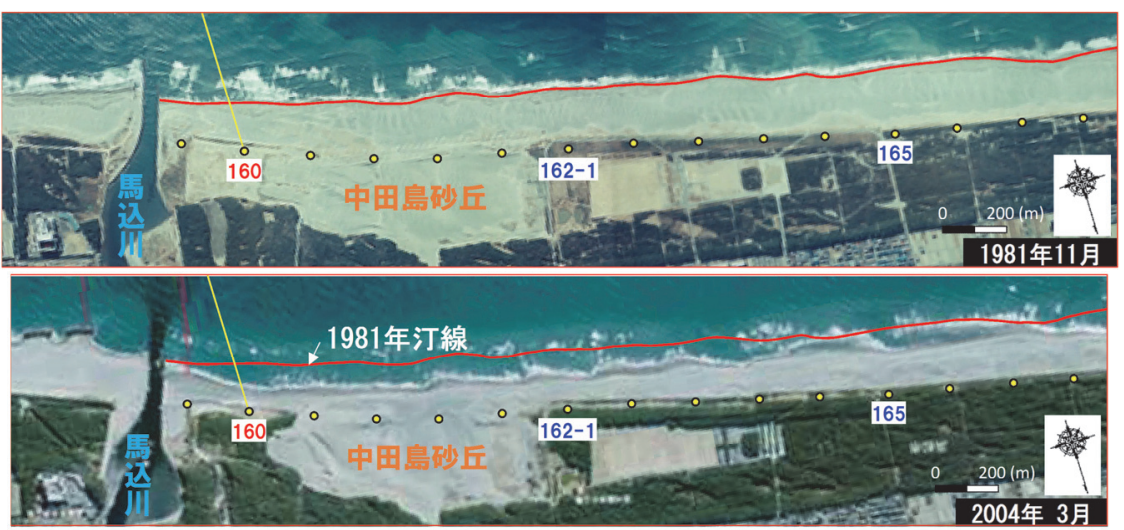

図-14＼cjkstart浜松篠海岸の変化（1981 年 vs 2004 年） 


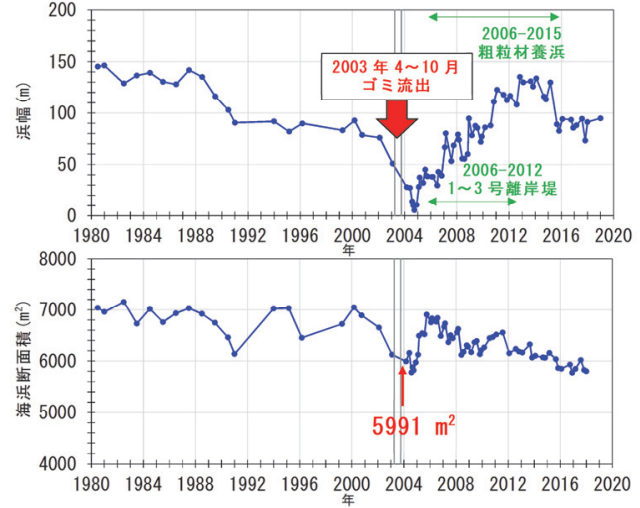

図-15＼cjkstart測線 No.160 における浜幅と海浜断面積の経年変化

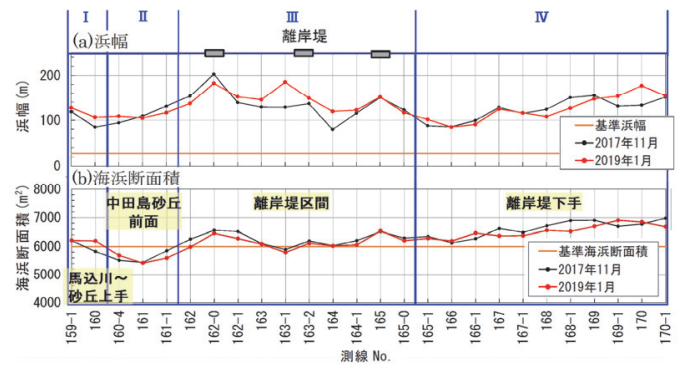

図-16 浜幅と海浜断面積の沿岸分布（浜松篠原海岸）

示す.この海岸ではいずれも場所も基準值を満足してい る. 海浜断面積もほぼ全域で基準值 $5991 \mathrm{~m}^{2}$ を満足して いるが，相対的に見ると中田島砂丘前面の区域 II では浜 幅は広いものの断面積の基準值を割り込んでいる.この 理由は粗粒材養浜により前浜付近に急勾配をなして土砂 が堆積したことによると考えられる. 図-17 には区域ご とに浜幅と海浜断面積の関係を示す. 区域 I と区域 IV で は両者とも基準值を満足している. 区域 II では浜幅は基 準值を満足しているが海浜断面積は基準值を下回った. 区域 III でも浜幅は十分広いが, 一部海浜断面積が基準值 を下回った.とくに 2 号離岸堤の東側直近を通る No.163-1 では基準断面積を割り込んでいる.
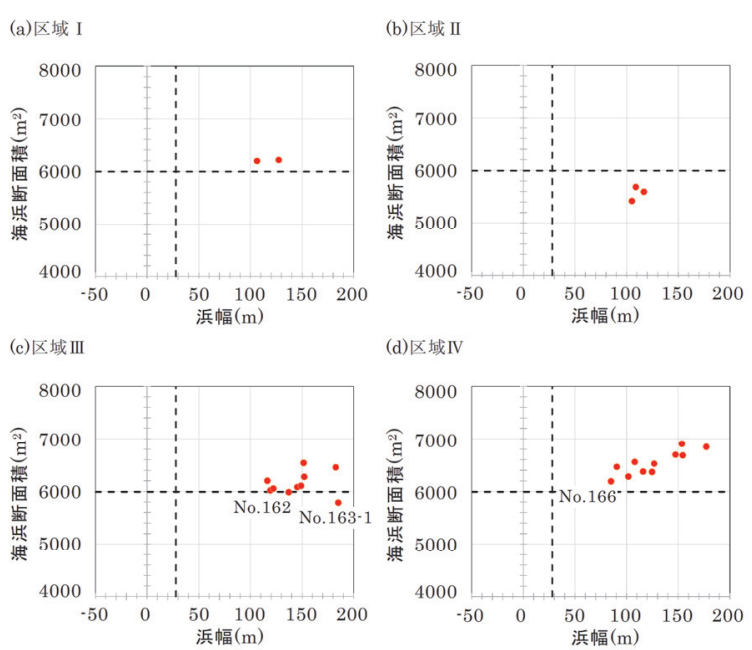

図-17 浜幅と海浜断面積の関係（浜松篠原海岸）

\section{4. まとめ}

遠州灘に面した竜洋・浜松五島・浜松篠原海岸を対象 として海岸堤防（土堤）の被災事例をもとに，浜幅と海 浜断面積より堤防の被災限界の目安を求め, さらにこの 限界值の目安を基準として設定することにより，堤防の 被災可能性の高い箇所を見出す一つの手法を明らかにし た.

\section{参考文献}

1) 宇多高明, 石川仁憲 : 砂浜が有する保全効果の評価手 法に関する一提案, 海岸, Vol.55, pp.52-55, 2018.

2) 宇多高明, 鈴木忠彦, 大石守伸, 山本雅彦, 大谷靖郎 : 竜洋海岸の侵食実態と河ロテラス縮小の影響, 海岸工 学論文集, 第 41 巻, pp.476-480, 1994.

3) 宇多高明, 長島郁夫, 横山卓司, 松浦吉洋, 古池 鋼, 石川仁憲 : 静岡県竜洋海岸の海浜変形予測, 海岸工学 論文集，第 55 巻, pp.666-670, 2008.

4) 長島郁夫, 岩崎伸昭, 宇多高明, 有村盾一: 遠州灘海 岸の天竜川河口以西の侵食実態, 海岸工学論文集, 第 52 巻, pp.596-600, 2005.

(Received February 6, 2020)

(Accepted May 1, 2020)

\section{CRITICAL LIMIT OF DAMAGE OF COASTAL DIKE IN TERMS OF BEACH WIDTH AND CROSS-SHORE AREA OF BEACH}

\section{Mitsuya HAKAMATA, Takaaki UDA and Masashi KAINUMA}

As the characteristic parameters to consider the damage potential of the stability of coastal dike associated with the shoreline recession, beach width in front of the coastal dike, which can be easily confirmed in the field, and cross-sectional area of the beach between the berm height $h_{\mathrm{R}}$ and the depth of closure $h_{\mathrm{c}}$ were considered. The examples at the Ryuyo, Hamamatsu-goto, and Hamamatsu-shinohara coasts were investigated. On the basis of the time changes in beach width obtained from the past aerial photographs and the cross-shore area of the beach calculated from the annual bathymetric survey, the critical limit for damage of the coastal dike was obtained. 